\title{
Effects of Meluadrine Tartrate and Ritodrine Hydrochloride on Oxytocin-Induced Uterine Contraction, Uterine Arterial Blood Flow and Maternal Cardiovascular Function in Pregnant Goats
}

\author{
Yoshio Matsuda $^{1, *}$, Satoshi Kouno ${ }^{2}$, Hiroshi Sakamoto ${ }^{3}$ and Tsuyomu Ikenoue ${ }^{4}$ \\ ${ }^{1}$ Department of Obstetrics and Gynecology, Tokyo Women's Medical University, \\ 8-1 Kawada-cho, Shinjuku-ku, Tokyo 162-8666, Japan \\ ${ }^{2}$ Department of Obstetrics and Gynecology, Kagoshima City Hospital, \\ 20-17 Kajiya-cho, Kagoshima City, Kagoshima 892-8580, Japan \\ ${ }^{3}$ Department of Veterinary Medicine, Faculty of Agriculture, Kagoshima University, \\ 1-21-24 Kohrimoto, Kagoshima City, Kagoshima 890-0065, Japan \\ ${ }^{4}$ Department of Obstetrics and Gynecology, Miyazaki Medical College, \\ 5200 Ohaza Kihara, Kiyotake-cho Miyazaki-County, Miyazaki 889-1692, Japan
}

Received February 7, 2002 Accepted July 9, 2002

\begin{abstract}
This study was designed to elucidate the effects of meluadrine tartrate on oxytocin-induced uterine contraction and maternal hemodynamics in unanesthetized, chronically instrumented pregnant goats. After the administration of meluadrine tartrate or ritodrine hydrochloride to pregnant goats, changes in heart rate (HR), arterial blood pressure (AOP), and arterial blood $\mathrm{pH}$ and gasses $\left(\mathrm{P}_{\mathrm{O}_{2}}\right.$ and $\mathrm{P}_{\mathrm{co}_{2}}$ ) in the mother, as well as changes in intrauterine pressure (IUP) and uterine arterial blood flow (UBF), were measured. The escalating administration of meluadrine tartrate $\left(0.03,0.1,0.3\right.$ and $\left.1 \mu \mathrm{g} \cdot \mathrm{kg}^{-1} \cdot \mathrm{min}^{-1}\right)$ or ritodrine hydrochloride $\left(1,3,10\right.$ and $\left.30 \mu \mathrm{g} \cdot \mathrm{kg}^{-1} \cdot \mathrm{min}^{-1}\right)$ to the maternal femoral vein caused a marked and similar inhibition in oxytocin-induced uterine contraction (a rise in IUP). By these escalating dosings, maternal HR was increased dose-dependently in both treatment groups; however, the degree of the HR increase in the meluadrine tartrate-treatment group was significantly less than that in the ritodrine hydrochloride-treatment group. Furthermore, the degree of the UBF decrease in the meluadrine tartrate-treatment group was significantly less than that in the ritodrine hydrochloride-treatment group. The present study suggests that meluadrine tartrate has a mild influence on the maternal cardiovascular function relative to the effects of ritodrine taking the potent efficacy on oxytocin-induced uterine contraction into account.
\end{abstract}

Keywords: Uterus, Goat, $\beta_{2}$-Adrenoceptor, Pregnancy, Heart rate

Meluadrine tartrate is a selective $\beta_{2}$-adrenoceptor agonist, which is being developed as a tocolytic agent for the treatment of premature labor. It was reported that meluadrine tartrate had a potent tocolytic activity in animal models. The relative potency of meluadrine tartrate was about 30 times as potent as ritodrine hydrochloride $(1-3)$. Ritodrine hydrochloride has been used as a tocolytic agent for a long time; however, it does have some side effects, of which palpitation and tachycardia are of particular concern. There were some clinical reports in which ritodrine hydrochloride might cause significant maternal tachycardia (410). In pregnant rats, meluadrine tartrate showed a potent

*Corresponding author. FAX: +81-5269-7350

E-mail: ymatsuda@obgy.twmu.ac.jp tocolytic activity and a good selectivity against the effect on maternal heart rate (HR) (1).

In the present study, we investigated the effects of meluadrine tartrate and ritodrine hydrochloride on oxytocininduced uterine contraction, uterine arterial blood flow (UBF), and maternal cardiovascular function in pregnant goats. Using our chronic preparation model of pregnant goats (11), we analyzed the meluadrine tartrate-induced changes in HR, arterial blood pressure (AOP), arterial blood $\mathrm{pH}$, arterial oxygen $\left(\mathrm{P}_{\mathrm{o}_{2}}\right)$ and carbon dioxide partial pressure $\left(\mathrm{P}_{\mathrm{co}_{2}}\right)$, and base excess, as well as changes in intrauterine pressure (IUP) and UBF in the mother.

Long-term administration is practical in the clinical situation, and consequently, it is considered necessary to investigate the long-term exposure of meluadrine tartrate in 
animal studies. Before the long-term study, however, we have been considering that it is necessary to compare the "short-term" effects of meluadrine tartrate and ritodrine hydrochloride, for which there have been many animal studies employing short-term administration $(12-15)$.

A preliminary account of these findings was presented at the 50th Annual Meeting of the Japan Society of Obstetrics and Gynecology.

\section{MATERIALS AND METHODS}

\section{Drugs and chemicals}

The following drugs were used: meluadrine tartrate ((-)(R)-2-tert-butylamino-1-(2-chloro-4-hydroxyphenyl)ethan1-ol mono-(2R,3R)-tartrate; Hokuriku Seiyaku Co., Ltd., Katsuyama), ritodrine hydrochloride (Sigma Chemicals, St. Louis, MO, USA), synthetic oxytocin (Hintocin ${ }^{\circledR}-\mathrm{O}$ for veterinary use; Sankyo, Tokyo). Meluadrine tartrate and ritodrine hydrochloride were dissolved in saline and sterilized by filtration via a Millex ${ }^{\mathrm{TM}}$ filter $(0.22 \mu \mathrm{m}$; Nihon Millipore Ltd., Tokyo).

\section{Animal preparation}

The studies were carried out on nine pregnant Japanese Saanen goats (ranging 18 to $32 \mathrm{~kg}$ in body weight), between 110 and 125 days of gestation. The animals were subjected to the experiments, after checking their clinical soundness by pre-operative examinations, including physical examination, clinical laboratory evaluation, radiography of the thorax and abdomen, and echographic evaluation of fetus. These goats were cared for in accordance with the guidelines approved by the Department of Veterinary Medicine of Kagoshima University for the care and use of animals.

The operation was divided into two steps to reduce surgical stress. The first operation was performed on mothers. A $4.7 \mathrm{~F}$ (French scale) polyethylene catheters (PE160; Imamura Co., Tokyo) were inserted into the femoral artery and vein, under local anesthesia. The goats were then kept without food or water for 24 to $48 \mathrm{~h}$ before the second operation.

The second surgical procedure was performed under anesthesia with ketamine hydrochloride $(10 \mathrm{mg} / \mathrm{kg}$, i.v.) and isoflurane. An incision was made in the peritoneum, and a blood flow meter probe (FH020T, FC-040T; Nihon Kohden Co., Tokyo or 3S859; Perivascular Flowprobe, Transonic Systems Inc., Ithaca, NY, USA) with an inner diameter of $2-4 \mathrm{~mm}$ was mounted on the middle uterine artery.

After this, the gravid uterus was exposed, and a $4.7 \mathrm{~F}$ polyethylene catheter was placed in the amniotic cavity for measurements of IUP.

The animals were allowed to recover for at least $48 \mathrm{~h}$ after surgery.

\section{Experimental protocol}

On the day of the experiment, the animal was allowed to sit quietly in her cage. Based on the changes in IUP, a uterine contraction was defined as a rise in IUP sustained for more than $30 \mathrm{~s}$. The uterine activity (UA) was estimated serially during successive 10-min intervals with Montevideo units; i.e., the number of uterine contractions (more than $5 \mathrm{mmHg}$ ) per 10 -min period multiplied by the mean intensity of uterine contractions. Uterine basal tone was considered as the lowest pressure between contractions during each 10-min period. Following the control period (Cont), oxytocin was administered via a $4.7 \mathrm{~F}$ polyethylene catheter which was placed in the external jugular vein on the first surgical day. The infusion rate of oxytocin was varied until stable uterine contractions of approximately 50 Montevideo units were achieved for at least $30 \mathrm{~min}$. This dose of oxytocin was then maintained throughout the remainder of the experiment. The mean infusion rate of oxytocin was 9.4 mI.U./min (S.E.M.; 1.5 mI.U., $\mathrm{n}=12$ ). After a 30-min oxytocin control period (Oxy), six goats received an escalating infusion of meluadrine tartrate via the femoral vein beginning at $0.03 \mu \mathrm{g} \cdot \mathrm{kg}^{-1} \cdot \mathrm{min}^{-1}$ for the first $30 \mathrm{~min}$ and then increased to $1 \mu \mathrm{g} \cdot \mathrm{kg}^{-1} \cdot \mathrm{min}^{-1}$ for the last $30 \mathrm{~min}$. Individual doses of $0.03,0.1,0.3$ and $1 \mu \mathrm{g}$. $\mathrm{kg}^{-1} \cdot \mathrm{min}^{-1}$ for $30 \mathrm{~min}$ totaled $2 \mathrm{~h}$ of infusion period. Six goats, including three goats that received meluadrine tartrate 2 days before or after the experimental day, received an escalating infusion of ritodrine hydrochloride beginning at $1 \mu \mathrm{g} \cdot \mathrm{kg}^{-1} \cdot \mathrm{min}^{-1}$ for the first $30 \mathrm{~min}$ and then increased to $30 \mu \mathrm{g} \cdot \mathrm{kg}^{-1} \cdot \mathrm{min}^{-1}$ for the last $30 \mathrm{~min}$. Individual doses of $1,3,10$ and $30 \mu \mathrm{g} \cdot \mathrm{kg}^{-1} \cdot \mathrm{min}^{-1}$ for $30 \mathrm{~min}$ totaled $2 \mathrm{~h}$ of infusion period. The doses of meluadrine tartrate and ritodrine hydrochloride were determined by the previous data in other species (1). Recovery was observed for $2 \mathrm{~h}$ after the termination of the drug infusion.

Maternal cardiovascular measurements and arterial blood sampling were obtained immediately before the start of the oxytocin infusion (Cont); before the start of the drug infusion (Oxy); at 30 (D-1), 60 (D-2), 90 (D-3) and $120 \mathrm{~min}$ (D-4) after the start of the drug infusion; and at 30 (R-30), 60 (R-60), 90 (R-90) and $120 \mathrm{~min}$ (R-120) after the termination of the drug infusion. The UA was calculated for $10 \mathrm{~min}$ before each above-mentioned time point during the experimental period. The mUBF value was calculated as the mean of three UBF measurements for each 5-min interval between $10 \mathrm{~min}$ before and each above-mentioned time point.

\section{Measurements of physiologic parameters}

Maternal HR, AOP and IUP were measured continuously via the catheters, which were connected to previously calibrated, sterile pressure transducers (4-327-C; Bell \& Howell, Los Angeles, CA, USA), an amplifier (7747; San- 
ei Co., Tokyo), and a tachometer (N4778, San-ei Co.). The UBF meter probe was connected to an electromagnetic blood flow meter (MFV-1200, Nihon Kohden Co. or T206, Transonic Systems, Inc.), which was then balanced. All the above data were recorded on a pensillograph (8K24-1-L, San-ei Co.).

The maternal arterial blood $\mathrm{pH}, \mathrm{P}_{\mathrm{O}_{2}}, \mathrm{P}_{\mathrm{co}_{2}}$, base excess and $\mathrm{HCO}_{3}$ were measured by a blood gas analyzer (AVL995; AVL Scientific Co., Roswell, GA, USA), and corrected for body temperature.

The plasma samples were frozen until the assay of meluadrine tartrate concentration in maternal arterial blood was done.

\section{Determination of the plasma concentration}

To $1 \mathrm{ml}$ of plasma sample, $0.1 \mathrm{ml}$ of water, $0.1 \mathrm{ml}$ of the internal standard aqueous solution, $1 \mathrm{ml}$ of $1 \mathrm{M}$ ammonium buffer ( $\mathrm{pH} 9$ ) and $6 \mathrm{ml}$ of diethyl ether were added. The whole mixture was shaken for $5 \mathrm{~min}$. Following centrifugation (3,000 rpm, $5 \mathrm{~min})$, the aqueous layer was frozen and the organic layer was transferred to another test tube and evaporated to dryness. Extraction was repeated with another $6 \mathrm{ml}$ of diethyl ether. The organic layer was combined with the residue. After the addition of $2 \mathrm{ml}$ of $0.1 \mathrm{M} \mathrm{HCl}$ to the organic layer, the tube was shaken for $5 \mathrm{~min}$. Following centrifugation $(3,000 \mathrm{rpm}, 5 \mathrm{~min})$, the aqueous layer was frozen and the organic layer was discarded. To the aqueous layer, $0.2 \mathrm{ml}$ of $1 \mathrm{M} \mathrm{NaOH}, 1 \mathrm{ml}$ of $1 \mathrm{M}$ ammonium buffer (pH 9) and $6 \mathrm{ml}$ of diethyl ether were added. The whole mixture was shaken for $5 \mathrm{~min}$. Following centrifugation (3,000 rpm, $5 \mathrm{~min})$, the aqueous layer was frozen and the organic layer was transferred to another test tube and evaporated to dryness. Extraction was repeated with another $6 \mathrm{ml}$ of diethyl ether. The organic layer combined with the residue was evaporated to dryness. The residue was reacted with $0.1 \mathrm{ml}$ of pentafluorobenzyl bromide (PFB; Aldrich, Milwaukee, WI, USA) in methanol $(20 \%$, $\mathrm{v} / \mathrm{v}$ ) and $0.1 \mathrm{ml}$ of $\mathrm{N}, \mathrm{N}$-diisopropylethylamine (DIPEA; Nacalai Tesque, Kyoto) in methanol $(5 \%, \mathrm{v} / \mathrm{v})$ at $40^{\circ} \mathrm{C}$ for $30 \mathrm{~min}$, and then the solvent was evaporated to dryness. The residue was reacted with $0.2 \mathrm{ml}$ of $\mathrm{N}, \mathrm{O}$-bis(trimethylsilyl)trifluoroacetamide (BSTFA; Wako Pure Chemicals, Osaka). The mixture was allowed to stand at room temperature for $15 \mathrm{~min}$. A $1-\mu 1$ aliquot of the mixture was injected into the GC-MS apparatus. For each run of the assays, accurately weighed meluadrine tartrate and internal standard was dissolved in water each separately to prepare 100and $10-\mu \mathrm{g} / \mathrm{ml}$ solutions, respectively. Standard solutions were prepared by appropriate dilutions with water to obtain standard solutions containing six points in the range of $0.2-10 \mathrm{ng} / \mathrm{ml}$. Plasma standard solutions were prepared at $0.02,0.05,0.1,0.2,0.5$ and $1 \mathrm{ng} / \mathrm{ml}$ of meluadrine tartrate by spiking a $0.1-\mathrm{ml}$ aliquot of each of the standard solutions. The internal standard solution was prepared by diluting with water to give concentration of $10 \mathrm{ng} / \mathrm{ml}$. Analyses were performed using a gas chromatography (GC: 5890 series II; Hewlett-Packard, Palo Alto, CA, USA) coupled with a mass spectrometer (MS: SX-102A; JEOL, Tokyo). A fused silica capillary column (30-m length and $0.32-\mathrm{mm}$ internal diameter, $0.25-\mu \mathrm{m}$ film thickness; DB-1; J\&W, Folsom, CA, USA) was used for the separation. Helium was used as the carrier gas at a column head pressure of $40 \mathrm{kPa}$. The thermal program consisted of an initial hold at $150^{\circ} \mathrm{C}$ for $1 \mathrm{~min}$, followed by a linear thermal program to $300^{\circ} \mathrm{C}$ at a rate of $30^{\circ} \mathrm{C} / \mathrm{min}$. The injection port was held at $200^{\circ} \mathrm{C}$. The aliquot was injected in the splitless mode, and the splitter was opened $1 \mathrm{~min}$ after completion of the injection. Mass spectrometry was performed in the negative ion chemical ionization mode. The selected-ionmonitoring analysis was conducted using m/z 224.084 and $\mathrm{m} / \mathrm{z} 233.140$ for both meluadrine and the deuterated meluadrine hydrochloride (Daiichi Pure Chemicals, Tokyo) as an internal standard, respectively. The assay method had the following specifications for meluadrine tartrate: lower limit of quantitation, $0.02 \mathrm{ng} / \mathrm{ml}$; linearity, $0.02-1 \mathrm{ng} / \mathrm{ml}$ $(r>0.999)$.

\section{Statistical analyses}

All values are expressed as the mean \pm S.E.M. The measurements immediately before the drug infusion were used as control values, so that the "Oxy" values were regarded as control values. The statistical difference between the meluadrine tartrate- and ritodrine hydrochloride-treatment groups in each parameter was analyzed by 2-way ANOVA followed by Tukey Kramer's method. The dosedependency in each treatment group was analyzed by Williams' multiple range test. Statistical differences between "Cont" and "Oxy" values in the various parameters were analyzed by the paired $t$-test. Differences in $P$ value less than 0.05 were considered to be statistically significant.

\section{RESULTS}

\section{Effects on oxytocin-induced uterine contraction}

The escalating administration of meluadrine tartrate $\left(0.03,0.1,0.3\right.$ and $\left.1 \mu \mathrm{g} \cdot \mathrm{kg}^{-1} \cdot \mathrm{min}^{-1}\right)$ or ritodrine hydrochloride $\left(1,3,10\right.$ and $\left.30 \mu \mathrm{g} \cdot \mathrm{kg}^{-1} \cdot \mathrm{min}^{-1}\right)$ caused a marked inhibition in oxytocin-induced uterine contraction (the increase in UA) dose-dependently (Fig. 1). In each treatment group, the inhibitory effects of all doses were statistically significant, and UA began to recover after the cessation of meluadrine tartrate- or ritodrine hydrochloride-infusion. Between two treatment groups, there were no statistical differences. The inhibitory degree of meluadrine tartrate at each dose was the same as that of ritodrine hydrochloride at each dose, which was approximately 30 times higher than 

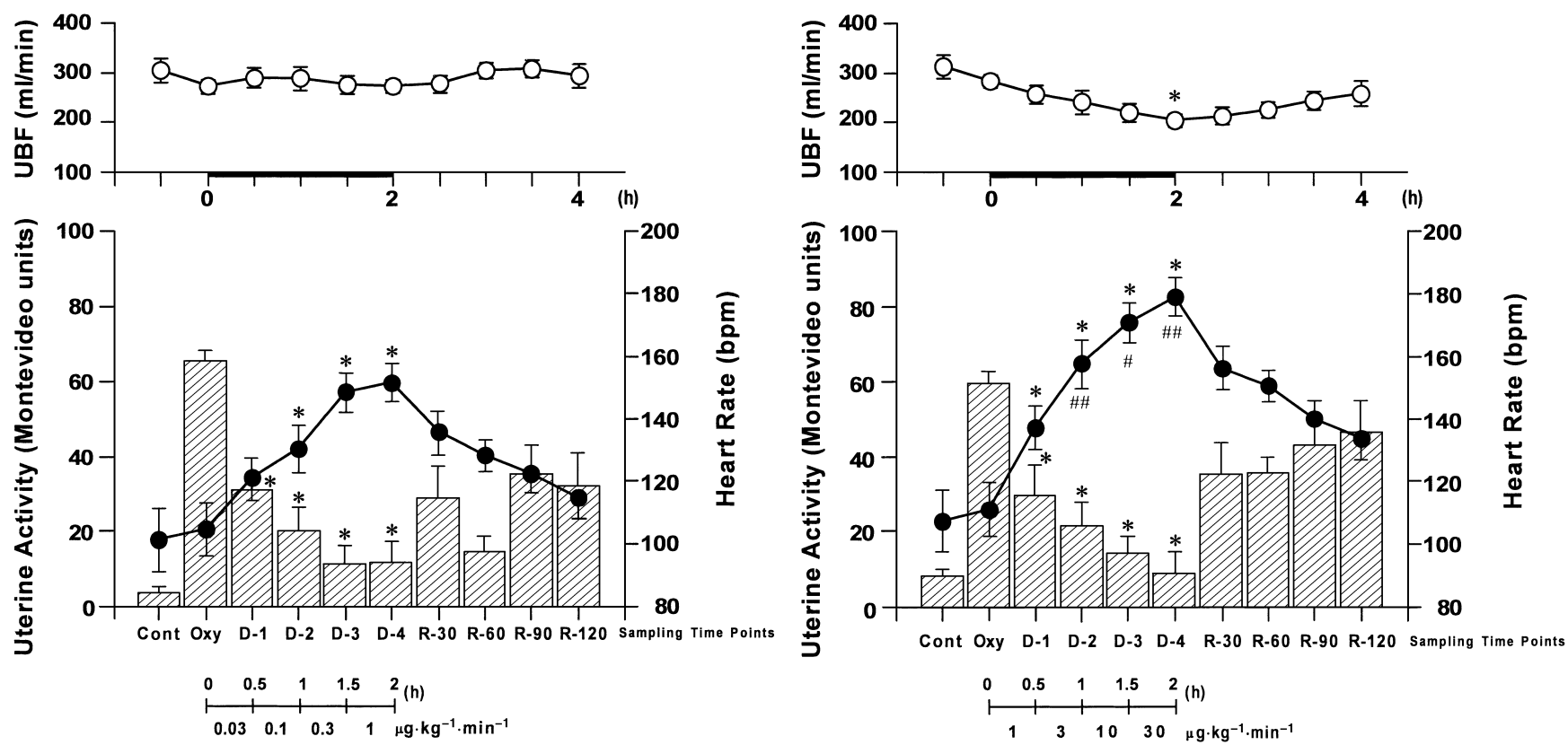

Fig. 1. Effects of meluadrine tartrate $(A, n=6)$ and ritodrine hydrochloride $(B, n=6)$ on oxytocin-induced uterine contraction (hatched column), maternal heart rate (closed circle) and uterine blood flow (open circle) in pregnant goats. Meluadrine tartrate in doses ranging from 0.03 to $1 \mu \mathrm{g} \cdot \mathrm{kg}^{-1} \cdot \mathrm{min}^{-1}$ or ritodrine hydrochloride in doses ranging from 1 to $30 \mu \mathrm{g} \cdot \mathrm{kg}^{-1} \cdot \mathrm{min}^{-1}$ was administered in an escalating manner to the maternal vein at 30-min intervals after the stable uterine contraction was achieved by a maintenance dose of oxytocin infusion (see text). Values are the mean \pm S.E.M. ${ }^{*} P<0.05$, compared with "Oxy" value. " $P<0.05$, ${ }^{\#} P<0.01$, comparison between meluadrine tartrate- and ritodrine hydrochloride-treatment groups.

Table 1. Effects of meluadrine tartrate and ritodrine hydrochloride on the maternal systolic, diastolic and mean blood pressure in pregnant goats

\begin{tabular}{|c|c|c|c|c|c|c|c|}
\hline Time points & & Cont & Oxy & D-1 & D-2 & D-3 & D-4 \\
\hline \multicolumn{8}{|c|}{ Meluadrine tartrate } \\
\hline Systolic & $(\mathrm{mmHg})$ & $114 \pm 10$ & $116 \pm 11$ & $115 \pm 11$ & $119 \pm 11$ & $115 \pm 11$ & $111 \pm 10$ \\
\hline Diastolic & $(\mathrm{mmHg})$ & $69 \pm 7$ & $72 \pm 7$ & $67 \pm 6$ & $67 \pm 4$ & $62 \pm 4$ & $60 \pm 5$ \\
\hline Mean & $(\mathrm{mmHg})$ & $84 \pm 8$ & $87 \pm 8$ & $83 \pm 7$ & $84 \pm 6$ & $80 \pm 6$ & $77 \pm 6$ \\
\hline \multicolumn{8}{|c|}{ Ritodrine hydrochloride } \\
\hline Systolic & $(\mathrm{mmHg})$ & $120 \pm 8$ & $120 \pm 8$ & $115 \pm 8$ & $118 \pm 10$ & $118 \pm 11$ & $116 \pm 9$ \\
\hline Diastolic & $(\mathrm{mmHg})$ & $72 \pm 5$ & $73 \pm 4$ & $67 \pm 6$ & $66 \pm 5$ & $61 \pm 7$ & $60 \pm 6$ \\
\hline Mean & $(\mathrm{mmHg})$ & $88 \pm 6$ & $89 \pm 4$ & $83 \pm 6$ & $83 \pm 6$ & $80 \pm 7$ & $78 \pm 7$ \\
\hline
\end{tabular}

Experimental conditions are the same as Fig. 1. Values are the mean \pm S.E.M.

the dose of meluadrine tartrate.

\section{Effects on maternal hemodynamics}

Maternal hemodynamics were not influenced by the oxytocin infusion $(P>0.05$ by paired $t$-test, Fig. 1 and Table 1). Maternal HR increased dose-dependently in both the meluadrine tartrate and ritodrine hydrochloride-treatment groups (Fig. 1). However, the degree of HR increase in the meluadrine tartrate-treatment group was significantly less than that in ritodrine hydrochloride-treatment group $(P<0.001$ by 2 -way ANOVA). The increases in HR were statistically significant at doses not less than 0.1 and $1 \mu \mathrm{g} \cdot \mathrm{kg}^{-1} \cdot \mathrm{min}^{-1}$ in the meluadrine tartrate- and ritodrine hydrochloride-treatment groups, respectively. The HR values began to recover after the cessation of meluadrine tartrate- or ritodrine hydrochloride-infusion. 
Table 2. Effects of meluadrine tartrate and ritodrine hydrochloride on the maternal blood $\mathrm{pH}$ and gasses in pregnant goats

\begin{tabular}{|c|c|c|c|c|c|c|c|}
\hline Time points & & Cont & Oxy & D-1 & D-2 & D-3 & D-4 \\
\hline \multicolumn{8}{|c|}{ Meluadrine tartrate } \\
\hline $\mathrm{pH}$ & & $7.465 \pm 0.014$ & $7.459 \pm 0.017$ & $7.447 \pm 0.019$ & $7.453 \pm 0.019$ & $7.438 \pm 0.025$ & $7.437 \pm 0.026$ \\
\hline $\mathrm{P}_{\mathrm{O}_{2}}$ & $(\mathrm{mmHg})$ & $102.3 \pm 4.3$ & $102.8 \pm 2.1$ & $98.2 \pm 2.9$ & $102.9 \pm 3.9$ & $99.1 \pm 3.1$ & $95.6 \pm 1.3$ \\
\hline $\mathrm{P}_{\mathrm{co}_{2}}$ & $(\mathrm{mmHg})$ & $29.0 \pm 1.1$ & $29.7 \pm 1.5$ & $30.0 \pm 1.1$ & $28.4 \pm 1.3$ & $28.8 \pm 1.2$ & $29.1 \pm 1.0$ \\
\hline $\mathrm{HCO}_{3}^{-}$ & $(\mathrm{mM})$ & $20.2 \pm 0.9$ & $20.5 \pm 1.0$ & $20.1 \pm 1.1$ & $19.3 \pm 0.9$ & $19.0 \pm 1.1$ & $19.2 \pm 1.2$ \\
\hline Base exes & $(\mathrm{mM})$ & $-1.4 \pm 1.0$ & $-1.3 \pm 1.1$ & $-1.9 \pm 1.3$ & $-2.4 \pm 1.0$ & $-3.0 \pm 1.4$ & $-2.9 \pm 1.5$ \\
\hline \multicolumn{8}{|c|}{ Ritodrine hydrochloride } \\
\hline $\mathrm{pH}$ & & $7.476 \pm 0.023$ & $7.465 \pm 0.023$ & $7.449 \pm 0.031$ & $7.430 \pm 0.019$ & $7.419 \pm 0.022$ & $7.414 \pm 0.022$ \\
\hline $\mathrm{P}_{\mathrm{O}_{2}}$ & $(\mathrm{mmHg})$ & $104.8 \pm 7.5$ & $103.5 \pm 7.2$ & $107.7 \pm 6.1$ & $99.9 \pm 5.1$ & $104.1 \pm 5.7$ & $103.2 \pm 6.6$ \\
\hline $\mathrm{P}_{\mathrm{co}_{2}}$ & $(\mathrm{mmHg})$ & $29.7 \pm 1.1$ & $31.8 \pm 1.4$ & $29.1 \pm 2.1$ & $30.6 \pm 0.9$ & $30.0 \pm 1.2$ & $27.6 \pm 2.6$ \\
\hline $\mathrm{HCO}_{3}^{-}$ & $(\mathrm{mM})$ & $21.2 \pm 0.7$ & $22.2 \pm 1.3$ & $19.4 \pm 0.9$ & $19.7 \pm 0.5$ & $18.8 \pm 0.7$ & $17.0 \pm 1.3$ \\
\hline Base exes & $(\mathrm{mM})$ & $-0.2 \pm 1.0$ & $0.2 \pm 1.4$ & $-2.4 \pm 1.1$ & $-2.7 \pm 0.9$ & $-3.7 \pm 1.0$ & $-5.2 \pm 1.2$ \\
\hline
\end{tabular}

Values are the mean \pm S.E.M.

The infusion of meluadrine tartrate or ritodrine hydrochloride did not influence the maternal systolic, diastolic and mean blood pressure (Table 1).

\section{Effects on maternal arterial blood $\mathrm{pH}$ and gasses}

Maternal arterial blood $\mathrm{pH}$ and gasses were not influenced by the oxytocin infusion $(P>0.05$, by paired $t$-test, Table 2). The infusion of meluadrine tartrate or ritodrine hydrochloride did not influence the maternal arterial blood $\mathrm{pH}, \mathrm{P}_{\mathrm{o}_{2}}, \mathrm{P}_{\mathrm{co}_{2}}, \mathrm{HCO}_{3}{ }^{-}$and base excess (Table 2).

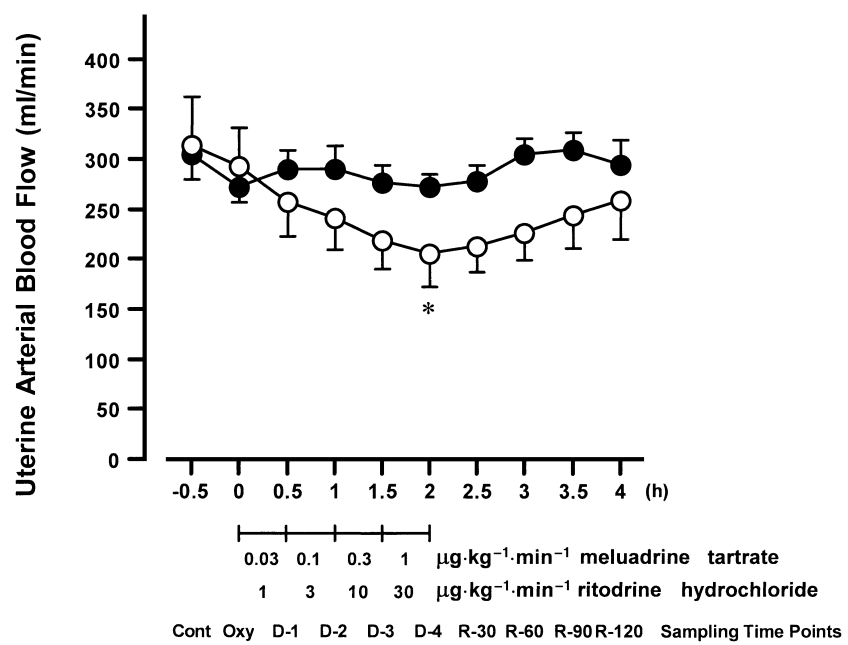

Fig. 2. Effects of meluadrine tartrate $(n=6)$ and ritodrine hydrochloride $(n=6)$ on the uterine arterial blood flow (closed circle for meluadrine tartrate and open circle for ritodrine hydrochloride) in pregnant goats. Experimental conditions are the same as Fig. 1. Values are the mean \pm S.E.M. $* P<0.05$, compared with "Oxy" value.

\section{Effects on uterine arterial blood flow}

Maternal uterine arterial blood flow was not influenced by the oxytocin infusion $(P>0.05$, by paired $t$-test). The mUBF values decreased in the ritodrine hydrochloridetreatment group, but not in the meluadrine tartrate-treatment group. Furthermore, this difference between two groups was statistically significant $(P<0.01$, by 2 -way ANOVA) (Fig. 2)

\section{Plasma concentration of meluadrine in maternal arterial blood}

The mean plasma concentration of meluadrine in maternal arterial blood increased in a dose-dependent manner in the meluadrine tartrate-treatment group (Table 3).

Table 3. Maternal plasma concentration of meluadrine in pregnant goats

\begin{tabular}{lc}
\hline Time points & Meluadrine $(\mathrm{ng} / \mathrm{ml})$ \\
\hline Oxy & N.D. \\
D-1 & $0.223 \pm 0.045$ \\
D-2 & $1.041 \pm 0.343$ \\
D-3 & $2.968 \pm 0.715$ \\
D-4 & $12.005 \pm 2.597$ \\
R-30 & $2.090 \pm 0.661$ \\
R-60 & $1.199 \pm 0.324$ \\
R-90 & $0.731 \pm 0.261$ \\
R-120 & $0.492 \pm 0.176$ \\
\hline
\end{tabular}

Experimental conditions were the same as Fig. 1. Arterial blood samples were obtained at each time point (see text). The measurement of plasma meluadrine concentration was done in only part of the animals of the meluadrine tartrate-treatment group. Values are the mean \pm S.E.M. of 4 animals. N.D.: Not detected $(<0.02 \mathrm{ng} / \mathrm{ml})$. 


\section{DISCUSSION}

The aim of this study was to elucidate whether it is possible to influence the maternal cardiovascular function and UBF when meluadrine tartrate was infused into the mother using a chronic preparation model of pregnant goats.

The inhibitory potency of meluadrine tartrate on oxytocin-induced uterine contraction was stronger than that of ritodrine hydrochloride in pregnant goats. This result was similar to those in previous studies of meluadrine tartrate in rats and rabbits $(1-3)$.

The degree of HR increase in the meluadrine tartratetreatment group was significantly less than that in the ritodrine hydrochloride-treatment group in pregnant goats. Hashimoto et al. (1) reported that the uterus/atrium selectivity of meluadrine tartrate was higher than that of ritodrine hydrochloride in in vitro studies using rat tissues. By a competitive experiment with ICI-118,511, reportedly a selective $\beta_{2}$-adrenoceptor antagonist, the inhibitory effect of meluadrine tartrate on the spontaneous rhythmic contraction in the uterine preparation isolated from pregnant rats was revealed to be mainly mediated through the $\beta_{2^{-}}$ adrenoceptor subtype $(1-3)$. By a competitive experiment with atenolol, a selective $\beta_{1}$-adrenoceptor antagonist, the positive chronotropic effect of meluadrine tartrate on the right atrial preparation isolated from pregnant rats was revealed to be mainly mediated through the $\beta_{1}$-adrenoceptor subtype (1). In addition, Hashimoto et al. reported that the degree of HR increase in meluadrine tartrate-treated rats was significantly less than that in ritodrine hydrochloride-treated rats (1). According to the results of the present study in pregnant goats, we confirmed that the uterus/atrium selectivity of meluadrine tartrate was higher than that of ritodrine hydrochloride, like it was in previous studies in pregnant rats.

There were some clinical reports in which ritodrine hydrochloride caused significant maternal tachycardia (410). The present result suggests the possibility that meluadrine tartrate has an advantage of low incidence of the cardiovascular side effects over ritodrine hydrochloride in future clinical use.

In the present study, we observed that ritodrine hydrochloride but not meluadrine tartrate reduced the MUBF in pregnant goats. The reduction of the mUBF during ritodrine hydrochloride infusion was reported in pregnant sheep $(15,16)$ and guinea pigs $(17,18)$. Fujimoto et al. $(15)$ mentioned two putative mechanisms of the decrease of uterine blood flow by ritodrine hydrochloride in the pregnant sheep in the discussion of their report. Firstly, the increase in blood flow to skeletal muscle might cause redistribution of cardiac output, leading to the decrease in uterine arterial blood flow. Secondly, an endogenous acti- vation of the sympathetic nervous system by irritation or restlessness might cause constriction of the uterine vasculature via $\alpha$-adrenergic receptors. Our result confirmed the effect of ritodrine hydrochloride on uterine blood flow in goats and suggested a ritodrine-specific mechanism such as the latter one mentioned by Fujimoto et al. (15). Another possibility is that ritodrine hydrochloride may have an agonistic activity towards $\alpha$-adrenergic receptors. This possibility has been considered but there is no evidence for it. In contrast to ritodrine hydrochloride, meluadrine tartrate did not influence the mUBF. Thus meluadrine tartrate apparently does not have the ability to activate the sympathetic nervous system endogenously.

In conclusion, the present study in pregnant goats clearly revealed that meluadrine tartrate had a potent tocolytic activity and mild influence on the cardiovascular function of the mother in comparison with ritodrine hydrochloride. These results show the possibility that meluadrine tartrate has the advantage of low incidence of cardiovascular side effects, compared to ritodrine hydrochloride, in future clinical use.

\section{REFERENCES}

1 Hashimoto S, Kawaguchi T, Yamauchi T, Ohashi T, Hosotani T, Morikawa K, Kato H and Ito Y: Inhibitory effect of HSR-81, a novel $\beta_{2}$-adrenoceptor agonist, on uterine contraction in late pregnancy. Jpn J Pharmacol 64, Suppl I, 211P (1994)

2 Ohashi T, Hashimoto S, Morikawa K, Kato H, Ito Y, Azuma H and Asano M: Potent inhibition of spontaneous rhythmic contraction by a novel $\beta_{2}$-adrenoceptor agonist, HSR-81, in pregnant rat uterus. Jpn J Pharmacol 64, Suppl I, 212P (1994)

3 Ohashi T, Hashimoto S, Morikawa K, Kato H, Ito Y, Asano M and Azuma H: Potent inhibition of spontaneous rhythmic contraction by a novel $\beta_{2}$-adrenoceptor agonist, HSR-81, in pregnant rat uterus. Eur J Pharmacol 307, 315 - 322 (1996)

4 Gamissans O, Esteban-Altirriba J and Maiques V: Inhibition of human myometrial activity by a new $\beta$-adrenergic drug (DU21220). J Obstet Gynaec Br Cwlth 76, 656- 662 (1969)

5 Spellacy WN, Cruz AC, Birk SA and Buhi WC: Treatment of premature labor with ritodrine: a randomized controlled study. Obstet Gynecol 54, 220 - 223 (1979)

6 Hollander DI, Nagey DA and Pupkin MJ: Magnesium sulfate and ritodrine hydrochloride: a randomized comparison. Am J Obstet Gynecol 156, 631 - 637 (1987)

7 Morales WJ, Smith SG, Angel JL, O’Brien WF and Knuppel RA: Efficacy and safety of indomethacin versus ritodrine in the management of preterm labor: a randomized study. Obstet Gynecol 74, 567 - 572 (1989)

8 The Canadian Preterm Labor Investigators Group: Treatment of preterm labor with the beta-adrenergic agonist ritodrine. $\mathrm{N}$ Engl J Med 327, 308 - 312 (1992)

9 Kupferminc M, Lessing JB, Yaron Y and Peyser MR: Nifedipine versus ritodrine for suppression of preterm labour. Br J Obstet Gynaecol 100, 1090 - 1094 (1993)

10 Black RS, Lees C, Thompson C, Pickles A and Campbell S: Maternal and fetal cardiovascular effects of transdermal glyceryl 
trinitrate and intravenous ritodrine. Obstet Gynecol 94, 572 576 (1999)

11 Matsuda Y, Ikenoue T, Matsuda K, Sameshima H, Ibara S, Hokanishi $\mathrm{H}$ and Sakamoto $\mathrm{H}$ : The effect of nicardipine on maternal and fetal hemodynamics and uterine blood flow in chronically instrumented pregnant goats. Asia-Oceania J Obstet Gynaecol 19, 191 - 198 (1993)

12 Ehrenkranz RA, Walker AM, Oakes GK, Mclaughlin MK, Ronald A and Chez RA: Effect of ritodrine infusion on uterine and umbilical blood flow in pregnant sheep. Am J Obstet Gynecol 126, 343 - 349 (1976)

13 Siimes ASI and Creasy RK: Effect of ritodrine on uterine activity, heart rate, and blood pressure in the pregnant sheep: Combined use of alpha or beta blockade. Am J Obstet Gynecol 126, $1003-1010(1976)$

14 Siimes ASI and Creasy RK: Maternal and fetal metabolic responses to ritodrine in the sheep. Acta Obstet Gynecol Scand 159, $181-186(1980)$
15 Fujimoto S, Akahane M, Uzuki K, Inagawa A, Sakai K and Ichinoe K: Effect of ritodrine hydrochloride on uterine activity and maternal and fetal circulations in the pregnant sheep. AsiaOceania J Obstet Gynaecol 9, 325 - 333 (1983)

16 McGrath JM, Chestnut DH, Vincent RD, DeBruyn CS, Atkins BL, Poduska DJ and Chatterjee P: Ephedrine remains the vasopressor of choice for treatment of hypotention during ritodrine infusion and epidural anesthesia. Anesthesiology 80, $1073-$ 1081 (1994)

17 Chestnut DH, Ostman LG, Weiner CP, Hdez MJ and Wang JP: The effect of vasopressor agents upon uterine artery blood flow velocity in the gravid guinea pig subjected to ritodrine infusion. Anesthesiology 68, 363 - 366 (1988)

18 Van de Walle AFGM and Martin CB: Effect of ritodrine on uteroplacental blood flow and cardiac output distribution in unanesthetized pregnant guinea pigs. Am J Obstet Gynecol 154, 189 - 194 (1986) 